\title{
Thermal Behaviour of the Ground
}

\section{Editorial}

This Géotechnique Symposium in Print was stimulated by the increasing interest in the ground as a source of energy. Yet this topic has been the subject of extensive research over the years, particularly in the fields of nuclear storage, agriculture, pipeline engineering and geothermal energy. This symposium created an opportunity to bring together a collection of papers from these different sectors which share a common interest in thermal behaviour.

The papers have been grouped together according to their position in the cycle of geotechnical researchcharacterisation, modelling, application and full-scale testing. In this issue there are thirteen articles covering modelling and application.

The papers on modelling focus on coupled thermohydraulic models that have been developed to study the effects of freezing and thawing of soils, predict the impact of climate change on ground conditions in cold regions, model the thermomechanical behaviour of soil, study the effect of temperature on failure, and use fractal analysis to study the evolution of cracks in soils. The application papers cover the use of ground embedded structures as heat exchangers, the use of aquifers as a thermal storage medium for heating and cooling, and the design of ground source systems.

The papers on thermomechanical models (Nishimura et al., 2009a; Thomas et al., 2009a; Abuel-Naga et al., 2009 and Thomas et al., 2009b) focus on the coupling of laws governing thermal, hydraulic and mechanical processes within an effective stress framework to create a unified approach to establish the impact of temperature and state changes on the porosity, stiffness and strength of soil. The models have been validated against in situ and small scale tests. Nishimura et al. (2009a) used their model to reproduce the behaviour of an in situ pipeline test (Slusarchuk et al., 1978). They were able to predict the heave and variation in porosity with some accuracy reflecting on the fact that the model, similar to the Modified Cam Clay model, replicates the effects of temperature on porosity and on strength. Thomas et al. (2009a) undertook a finite element (FE) analysis to show the effects of soil freezing from the surface and freezing from above and below for soils in permafrost zones. This study helps develop an understanding of solifluction processes. Abuel-Naga et al. (2009) have developed a validated model to predict thermally-induced volume changes of saturated clay subject to isotropic stress state. They have extended that to validate their model for different clays subject to a triaxial stress state by adopting the Modified Cam Clay model. Thomas et al. (2009b) developed a coupled thermo-hydro-mechanical model for unsaturated soil which they validated against high temperature laboratory tests on triaxial specimens subjected to temperature and hydraulic gradients. Tang and Cui (2009) also developed a model for use with compacted expansive clays to show that they could predict the volume changes of partially saturated bentonite subject to temperature changes. These two papers are results of studies into the behaviour of compacted clay used in storage of high-level nuclear waste, a topic covered in the next issue.

Hueckel et al. (2009) have studied the impact of stress and temperature on failure. They interpreted four case studies to reach a conclusion that thermal failure may occur even if mechanical failure is not imminent. They also highlight the fact that various authors have conflicting views of the links between strength and temperature giving rise to a suggestion that the link between thermomechanical history and strength must take into account the soils' physical and chemical characteristics. They conclude that there is no unique yield surface for a given temperature.

While many of the papers are concerned with the thermal characteristics at depth, Vallejo (2009) uses the concept of fractal dimensions to predict the effect of desiccation on the surface of clays which is of importance to landfill liners. The concept can also be applied to rocks in which the variation in coefficient of expansion of the mineral grains creates factures.

An interesting paper by Nishimura et al. (2009b) has made use of meteorological data to predict the degradation of permafrost due to the impact of climate change. The approach has been used to predict geocryological changes from 1949 to 2059 for a region in Siberia. The model demonstrates that elevation, vegetation and local geology all affect the development of permafrost. The model can be used to predict the temperature at depth and the depth of the permafrost zone, which has implications for existing and proposed infrastructure, thus creating a hazard map.

The development of constitutive models allows the development of guidelines for ground energy systems, a number of which are presented here. For example, there is extensive experience of the use of geotechnical structures as heat exchangers in a number of countries, 
such as those described by Adam and Markiewicz (2009); a range of structures in Austria to show how they have been used to abstract heat from the ground and to deposit heat into the ground. These are known as closed-loop systems because the heat is conveyed by fluid travelling through pipes embedded in the structures. In particular they focus on tunnels and associated structures demonstrating the use of geothermal energy on major infrastructure projects. Bourne-Webb et al. (2009) describe in detail the results of a pile load test on a pile subject to thermal cycles. This enabled them to observe the effect thermal loading has upon the settlement of the pile and the zone of influence of the thermal pile. They concluded that the structural capacity of the pile is unaffected by the thermal cycles. Wood et al. (2009) describe tests on a typical piled foundation for a domestic house to demonstrate that the concept is entirely feasible for such structures.

An alternative to the use of the ground as a source of heat is to use groundwater as a source of heat. In open systems the water is pumped from depth to the surface. This raises a number of environmental issues relating to the abstraction of groundwater and disposal of the water. An alternative is to install heat exchangers at the surface and pump groundwater from the aquifer to the surface heat exchangers and back to the aquifer. This has the advantage, as with geotechnical structures, that the ground can be used as a heat source and heat sink. Dickinson et al. (2009) describe such a system, known as the aquifer thermal energy storage system (ATES). They have compared the predicted behaviour with five years of observations from an office building in the Netherlands and found reasonable agreement. They do highlight the need to control the use of the ground as an energy source and ensure that all systems are thermally balanced.

Preene and Powrie (2009) provide a useful overview of the design process for ground energy systems highlighting the geotechnical hazards both in the short and long term. This leads onto recommendations for ground investigations and designs for such systems. They also emphasise the need for balanced systems.

Thus this selection of papers presents a range of international views on the thermal behaviour of the ground and how that behaviour can be modelled. Examples are given of the use of the ground as a source of energy demonstrating the opportunities that exist. Producing a Symposium in Print is demanding because there is a deadline to meet. The efforts of the authors, assessors, reviewers and publication team have led to this successful compilation of papers covering thermal behaviour of the ground.

\section{B. G. Clarke}

\section{Symposium in Print Sub-Committee Chairman}

Professor Barry G. Clarke, University of Leeds

\section{Sub-Committee Members}

Mr Robin Curtis, EarthEnergy Ltd

Dr Domenico Gallipoli, University of Glasgow

Dr John R. McDougall, Napier University

Dr Duncan Nicholson, Ove Arup \& Partners

Dr Brian Simpson, Ove Arup \& Partners

Dr Jamie R. Standing, Imperial College London

\section{REFERENCES}

Abuel-Naga, H. M., Bergado, D. T., Bouazza, A. and Pender, M. (2009). Thermomechanical model for saturated clays. Géotechnique 59, No. 3, 273-278.

Adam, D. \& Markiewicz, R. (2009). Energy from earth-coupled structures, foundations, tunnels and sewers. Géotechnique 59, No. 3, 229-236.

Bourne-Webb, P. J., Amatya, B., Soga, K., Amis, T., Davidson, C. and Payne, P. (2009). Energy pile test at Lambeth College, London: geotechnical and thermodynamic aspects of pile response to heat cycles. Géotechnique 59, No. 3, 237-248.

Dickinson, J. S., Buik, N., Matthews, M. C. \& Snijders, A. (2009). Aquifer thermal energy storage: theoretical and operational analysis. Géotechnique 59, No. 3, 249-260.

Hueckel, T., François, B. \& Laloui, L. (2009). Explaining thermal failure in saturated clays. Géotechnique 59, No. 3, 197-212.

Nishimura, S., Gens, A., Olivella, S. \& Jardine, R. J. (2009a). THM-coupled finite element analysis of frozen soil: formulation and application. Géotechnique 59, No. 3, 159-171.

Nishimura, S., Martin, C. J., Jardine, R. J. \& Fenton, C. H. (2009b) A new approach for assessing geothermal response to climate change in permafrost regions. Géotechnique 59, No. 3, 213227.

Preene, M. \& Powrie, W. (2009). Ground energy systems: from analysis to geotechnical design. Géotechnique 59, No. 3, 261271.

Slusarchuk, W. A., Clark, J. I., Nixon, J. F., Morgenstern, N. R. and Gaskin, P. N. (1978). Field test results of a chilled pipeline buried in unfrozen ground. Proc. 3rd Int. Conf. on Permafrost, Edmonton 1, 878-883

Tang, A-M. \& Cui, Y.-J. (2009). Modelling the thermomechanical behaviour of compacted expansive clays. Géotechnique 59, No. 3, 185-195.

Thomas, H. R., Cleall, P., Li, Y.-C., Harris, C. \& Kern-Luetschg, M. (2009a). Modelling of cryogenic processes in permafrost and seasonally frozen soils. Géotechnique 59, No. 3, 173-183.

Thomas, H. R., Siddiqua, S. and Seetharam, S. C. (2009b). Inclusion of higher-temperature effects in a soil behaviour model. Géotechnique 59, No. 3, 279-282.

Vallejo, L. E. (2009). Fractal analysis of temperature-induced cracking in clays and rocks. Géotechnique 59, No. 3, 283-286.

Wood, C. J., Liu, H. and Riffat, S. B. (2009). Use of energy piles in a residential building, and effects on ground temperature and heat pump efficiency. Géotechnique 59, No. 3, 287-290. 